formed the subject of a paper by Dr. Kuntzel, who showed that this material is taken up by the basic groups of the hide substance molecule, and acts generally like the synthetic tannins.

A conclusion arrived at in a paper by Dr. E. Elod on the dyeing of leather is that if a series of acid or direct dyes be arranged in order of their dissociation constants, such order represents also their relative fastness to washing. The importance of drying in leather manufacture was discussed by Dr. K. Wolf, who mentioned that drying occurs in two stages, first the evaporation of the loosely held water, and secondly the loss of bound water, this latter being governed by the type of tannage and degree of tannage of the leather. Dr. W. Grassmann dealt with the chromatographic adsorption analysis of tanning materials. This depends on passing the solution through a tube of an adsorbent material (silica gel, kaolin, etc.) when a characteristic separation occurs, the strongly adsorbed constituents being retained in the upper layers while other constituents infiltrate to various depths. The preparation of sulphite cellulose extracts was discussed by $\mathrm{L}$. Masner and V. Samec, and Dr. W. Hausam described certain pin hole defects in calf and goatskin.

Prof. Leplat gave an interesting lecture on the need for closer co-operation between the histologist and leather technologist, and showed how the newer science of histo-chemistry has been able to differentiate structural differences between tendon fibre and skin substance, which may account for their different behaviour on acid swelling.

\title{
Higher Agricultural Education in Great Britain
}

$\mathrm{T}$ HE Report of the Departmental Committee on the Reassessment of Annual Grants to Institutions providing Higher Agricultural (excluding Veterinary) Education in England and Wales, 1934, is regarded by the Minister of Agriculture as of such importance that the non-confidential portions have been reproduced in full in the Journal of the Ministry of Agriculture of August 1935. It is understood, how. ever, that some of the recommendations have already been implemented.

The fifteen institutions concerned, comprising agricultural colleges and university departments of agriculture, were visited by members of the Committee, and all available information as to work and finances considered in detail. The Committee lays great stress on the importance of education and research for the development of agriculture, quoting many specific instances where the results of research have materially altered the methods of agricultural practice. The importance of the agricultural colleges lies in the fact that experience shows that the farmers who are the first to introduce improved methods on their own farms and, indirectly, to their neighbours, are those who have received training at a college or farm institute. Any attempt to reorganise the agricultural industry in Great Britain must, therefore, ensure that the agricultural colleges are on such a footing that they can perform their functions with efficiency.

The attitude of the Committee was sympathetic and liberal, the object being to make such recommendations as would ensure the financial stability of each institution, without countenancing any waste or unnecessary expenditure of public money. At the same time, it was agreed that it is a mistake to penalise an institution that is successful, and that one that is so well managed that it pays its way should not on that account alone suffer a reduction in its grant. The financial crisis of 1931 prevented any increases in grants, and caused reductions in many cases, and as lowered incomes from this and other sources mean reduced expenditure, the position of the colleges in 1934 was one of stagnation due to lack of funds, rendering them unable to play their full part in the leadership of the agricultural industry.

Most of the colleges work in direct relation to the surrounding county areas; but the amount of local financial support varies considerably, both as regards direct grants and the award of scholarships, and in some cases this support is far from adequate. An increase in both types of financial aid from certain counties is very desirable, together with a greater co-operation for making the facilities provided by the colleges more widely known.

In most cases the existing staff is adequate to meet present demands, but the level of the salaries paid leaves much to be desired. This, added to the salary cut imposed in 1931, has resulted in deplorable conditions in certain specified colleges, and recommendations have been made for extra grants to improve conditions.

One result of the 1931 depression has been a fall in the number of fee-paying students, with a certain increase in scholarship holders, and in some eases the quality of the students is less good than formerly. It is recommended that the colleges should be pressed to satisfy themselves that all their students are suitably equipped to benefit by their course of instruction, and that a more rigorous attitude should be adopted in the weeding-out of students who are not availing themselves of their opportunities. At the same time, it is desirable that every effort should be made to increase the numbers of students drawn directly from agricultural circles, which can be encouraged by scholarships given by the Ministry and by county authorities. There seems to be scope for a much greater measure of county assistance in this respect.

The attention of the Committee was also directed to the question of adequate farm areas attached to the colleges. Although most colleges already possess such farms, in some cases they might be used more freely for the practical instruction of the students. For urban colleges, the distance to the farm may present difficulty, and in one instance the establishment of a local farm institute on the farm itself has been recommended as the condition of the continuance of the existing grant.

In spite of the reduced incomes, due to various causes, it is most undesirable that any increase in the level of fees paid by students should be made, as even now the cost is too heavy for members of the agricultural classes without the aid of scholarships or reduced fees. The heavy burdens of interest charges and bank overdrafts could best be dealt with 
by increases of grant sufficient for their gradual reduction. Considerable items of capital expenditure still call for the Ministry's contribution on a pound for pound basis; but if possible, smaller items should be met out of a margin provided by an adequate annual grant.

As a measure of security for the proper use of the suggested increased grants, the report proposes that annual visits should be paid to colleges and farms by responsible officials and technical officers of the
Ministry. It also recommends that members of the county committees should periodically visit any college to which a grant is made, with the view of increasing the co-operation between colleges and counties.

If the suggestions outlined above are put into force, the position of the agricultural colleges of Great Britain will be greatly strengthened, and they will be enabled to make a much greater contribution towards improving agricultural practice throughout the country.

\section{International Longitude Operations}

$\mathrm{T}$ HE Observatory of Zi-Ka-Wei, which took part in the International Programme of Longitude Operations in October and November 1933, in addition to transmitting its results to the Commission of the International Astronomical Union responsible for the general reduction of the whole work, has published its own observations in its Annales (t. 20).

The Observatory kept its own time with two pendulums, Leroy 1227 and 1338, working at constant pressure and a temperature controlled by a thermostat. Meridian observations were made with two transit instruments, the $\mathrm{Zi}-\mathrm{Ka}$.Wei instrument used in 1926 and a similar instrument which was brought from Nice by M. Fayet. Observations with both instruments were secured on twenty-eight nights by four observers, each of whom used both instruments. The maximum difference between the clock errors deduced from the two instruments on the same night was $0 \cdot 04^{\mathrm{s}}$, and the difference was generally less than $0.02 \mathrm{~s}$. Wireless time signals were received from a number of stations, including DFY (Nauen) and FYL (Bordeaux). Time lags in the reception of the wireless signals were determined by a method due to M. Jouast, and it is hoped that their effect has been eliminated. The longitude of $\mathrm{Zi}-\mathrm{Ka}$-Wei minus Paris is found to be $7^{\mathrm{h}} 56^{\mathrm{m}} 21.962^{\mathrm{s}}$ in 1933 , as compared with $21.975^{\mathrm{s}}$ in 1926. The difference between the two determinations is thus $0.015^{\mathrm{s}}$ (the equivalent of $17 \mathrm{ft}$. on the earth's surface) which is presumably scarcely outside the limit of accidental error ; but it is of interest from the point of view of continental drift to note that observations of this kind would certainly have shown up a drift of seventy feet on the earth's surface during the seven years that elapsed between the two determinations. It is certain that the reality or otherwise of continental drift will be settled by these precise longitude observa. tions, when a long enough time interval has elapsed.

The director of the $\mathrm{Zi}-\mathrm{Ka}$-Wei Observatory directs attention to a puzzling periodic variation from the mean longitude with an amplitude of $0.05^{\mathrm{s}}$ and period of one month. This is shown by the 1933 observations as well as by those made in 1926. $\mathrm{He}$ concludes that it is not possible to incriminate either the meridian observations or the reception of the time signals, and is inclined to attribute these fluctuations to a periodic deformation of the earth's crust. One is reminded of a somewhat similar effect in the longitude difference Washington minus Greenwich, which has been pointed out by Loomis and Stetson. The precise nature of the cause of this variation is obscure.

\section{Biology and Variation of Ceratium}

\begin{abstract}
WHE introductory report* (No. 1) to the Carlsberg Foundation's Oceanographical Expedition contains an article in memory of its late leader, Prof. Johannes Schmidt, by Martin Knudsen, with portrait, a foreword by P. Jespersen and $\AA$. Vedel Tåning, a list of stations and, finally, the results with detailed tables of the echo-soundings, with introductory remarks by Sv. Greve. There are also seven maps showing the stations.

This was the last and the greatest of the many expeditions in which Schmidt personally took part, from June 14, 1928, until June 30, 1930. Like all those which he conducted, it was planned and con-

* The Carlsberg Foundation's Oceanographical Expedition round the World 1928-30 and Previous Dana Expeditions under the Leadership of the late Prof. Johannes Schmidt. Dana-Report No. 1. Introduction to the Reports from the Carlsberg Foundation's Oceanographical Expedition round the World 1928-30. Pp. $130+7$ plates. 168. net. No. 4. Untersuchungen über die Verbreitung, Biologie und Variation der Ceratien im sidiliches stillen Ocean, von E. Steemann Nielsen Oxford University Press, 1934.)
\end{abstract}

ceived in every detail by himself. He took care that the investigations were as many-sided as possible, and maintained his interest in discovering connexions between the biological and physico-oceanographical conditions. The principal features in the biologicalzoogeographical methods of work and the plans for the Expedition were drawn up by him in the following summary :-

(1) With the aid of the most efficient apparatus to obtain a very large material, rich in individuals, of the pelagic life in the different depths and the various oceans.

(2) With the aid of simultaneous, methodical investigations on the physical and chemical com. position of the different water layers, to obtain data which would permit us to conclude under what environmental conditions each single one of the millions of pelagie organisms, taken in the nets, may live. 